\title{
PENDIDIKAN DAN PELATIHAN PEMBUATAN MEDIA PEMBELAJARAN AUDIOVISUAL BAGI GURU-GURU SEKOLAH DASAR DI DESA MALOLA KECAMATAN KUMELEMBUAI
}

\author{
Maxie Albert Jacob Liando ${ }^{1}$ \& Oldy J. Tamunu ${ }^{2}$ \\ ${ }_{1}^{1}$ Program Studi Pendidikan Guru Sekolah Dasar, Fakultas Ilmu Pendidikan \\ 2Program Studi Pendidikan Teknik Informatika dan Komunikasi, Fakultas Teknik, \\ Universitas Negeri Manado (UNIMA)
}

\begin{abstract}
Abstrak
Pengembangan soft skills pada guru sekolah dasar dapat dipenuhi melalui model pembelajaran Multimedia berbasis Teknologi Informasi Komunikasi (TIK). Salah satu model yang dapat didesain adalah media pembelajaran audiovisual. Karenya guru-guru yang ada di Desa Malola dan Malola Satu Kecamatan Kumelembuai perlu diberi pelatihan pembuatan media seperti ini. Pelatihan pengembangan media pembelajaran audiovisual berbasis Teknologi Informasi dan Komunikasi bertujuan untuk memberikan keterampilan kepada guru sekolah dasar di Desa Malola dalam pembuatan media pembelajaran audiovisual yang menarik dengan cara yang relatif mudah. Metode yang diterapkan dalam kegiatan ini adalah Metode Presentasi, Demonstrasi dan Praktek. Metode Presentasi digunakan untuk pengenalan software meliputi Microsoft Power Point Hyperlink. Metode Demonstrasi mengenai pengoperasionalisasian program dan Metode Praktek yaitu pembuatan media pembelajaran secara langsung oleh guru sesuai dengan tema atau mata pelajaran yang diampu oleh guru kelas atau guru mata pelajaran dengan pemanfaatan program-program tersebut. Hasil yang diharapkan dalam Diklat ini adalah: Pertama, Pelatihan memberikan beberapa materi yang terkait dengan upaya meningkatkan kualitas pembelajaran dengan pemberian pengetahuan mengenai pemanfaatan Program Powerpoint Hyperlink untuk membuat audiovisual sebagai media pembelajaran berbasis TIK yang atraktif dan interaktif, Kedua, Materi yang disajikan dapat diterima, dicerna, dan dipahami peserta dengan baik, Ketiga, Kegiatan berlangsung lancar, tepat waktu dan sesuai dengan yang diharapkan.
\end{abstract}

Kata Kunci: Media, audiovisual, Guru SD, Malola.

\section{PENDAHULUAN}

\section{Analisis Situasi}

Bangsa Indonesia dewasa ini telah berupaya keras meningkatkan proses pendidikan dan pengajaran melalui berbagai kebijakannya. Pemberlakuan UU RI No. 14 Tahun 2005 berkonsekuensi setiap guru harus memiliki kompetensi. Kompetensi adalah seperangkat tindakan cerdas dan penuh tanggung jawab yang dimiliki seorang sebagai syarat untuk dianggap mampu oleh masyarakat dalam melaksanakan tugas-tugas dibidang pekerjaan tertentu (Keputusan Mendiknas No 045 Tahun 2002). Di era informasi terjadi pergeseran fokus pengembangan kompetensi SDM, yakni guru dituntut lebih professional.

Menurut Journal Education Leadership, ukuran seorang guru dinyatakan profesional adalah: memiliki komitmen pada siswa dan proses belajarnya; secara mendalam menguasai bahan ajar dan cara mengajarkannya; bertanggung jawab memantau kemampuan belajar siswa melalui berbagai teknik evaluasi; seyogianya menjadi bagian 
dari masyarakat belajar dalam lingkungan profesinya (Aqib, 2009). Secara teknis, kegiatan yang dapat dilakukan untuk meningkatkan kompetensi guru adalah (1) bimbingan dan tugas, (2) pendidikan dan pelatihan, (3) kursus-kursus, (4) studi lanjut, (5) promosi, (6) latihan jabatan, (7) rotasi jabatan, (8) konferensi, (9) penataran, (10) lokakarya, (11) seminar, dan (12) pembinaan profesional guru (Supervisi Pengajaran, Dantes, 2006).

Pelatihan itu harus dibuat dengan sistem yang canggih. Mesti dipastikan sesudah pelatihan, guru mempunyai keterampilan yang memadai yang didukung dengan support system. Perubahan cepat dalam teknologi informasi dan teknologi pembelajaran bukan menjadi penghalang bagi guru sebagai sumber dan aktor pendidikan yang utama, melainkan menjadi tantangan yang menuntut kompetensi profesional guru yang lebih tinggi.

Guru dituntut memiliki kemampuan membangkitkan semangat dan kesadaran diri peserta didik sehingga mereka terbiasa belajar. Dalam konteks ini, guru harus memiliki kemampuan mengoptimalkan berbagai kemampuan belajar peserta didik untuk selalu dalam kondisi prima dan semakin giat dalam belajar. Adapun cara yang dapat dilakukan adalah perekayasaan pembelajaran. Perekayasaan pembelajaran berarti guru merancang, mengembangkan, melaksanakan, mengevaluasi, dan menyempurnakan kegiatan pembelajaran sesuai kebutuhan peserta didik. Kegiatan pembelajaran dipandang sebagai kegiatan yang dinamis dan inovatif yang perlu dimutahirkan secara terus menerus. Dalam hal ini guru harus menguasai substansi bidang studi dan metodologi keilmuan serta menguasai dan memanfaatkan teknologi informasi dan komunikasi dalam pembelajaran. Strategi belajar mengajar yang dipilih, ditentukan metode mengajarnya, untuk bidang studi/topik tertentu, teknik mengajar, dan akhirnya kita pilih alat peraga atau media pembelajarannya.

Menggunakan media pembelajaran harus sesuai dengan karakteristik peserta didik untuk mencapai tujuan pembelajaran secara utuh. Media pembelajaran tendiri dari: media yang tidak diproyeksikan, media yang diproyeksikan, media audio, media video, media berbasis komputer, dan multi media. Media Pembelajaran Audiovisual adalah satu unit media pembelajaran elektronik yang secara bersama-sama menampilkan auditif (pendengaran) dan visual (penglihatan) sebagai sumber belajar dan sebagai penyalur informasi dari bahanbahan pelajaran yang disampaikan guru kepada peserta didik dalam proses belajar mengajar. Media audiovisual adalah media yang mampu merangsang indra penglihatan dan indra pendengaran secara bersamasama, karena media ini mempunyai unsur suara dan unsur gambar (Djamarah, 2006: 124). 
Media ini sangat membantu guru dalam pembelajaran karena dapat mengurangi verbalisme sehingga pembelajaran dapat menarik dan lebih konkrit. Sayangnya media pembelajaran ini masih jarang digunakan oleh guru dalam kegiatan belajar mengajar. Padahal belajar tidak hanya bersentuhan dengan hal-hal yang kongkrit, baik dalam konsep maupun faktanya. Bahkan dalam realitasnya belajar seringkali bersentuhan dengan hal-hal yang bersifat kompleks, maya dan berada di balik realitas. Karena itu, media memiliki andil untuk menjelaskan hal-hal yang abstrak dan menunjukkan hal-hal yang tersembunyi. Ketidakjelasan atau kerumitan bahan ajar dapat dibantu dengan menghadirkan media sebagai perantara. Bahkan dalam hal-hal tertentu media dapat mewakili kekurangan guru dalam mengkomunikasikan materi pelajaran. Keinginan untuk mengembangkan dan meningkatkan kompetensi guru dalam tugasnya sebagai tenaga pendidik, akan diejawantahkan dalam bentuk pendidikan dan pelatihan pembuatan media pembelajaran audiovisual bagi guru sekolah dasar di Desa Malola dan Malola Satu Kecamatan Kumelembuai.

Desa Malola dan Malola Satu adalah desa yang terletak di kaki gunung Lolombulan dan masuk dalam wilayah Kecamatan Kumelembuai Kabupaten Minahasa Selatan Propinsi Sulawesi Utara. Kedua Desa ini diapit oleh dua buah sungai yakni sungai Sondaken di sebelah utara dan sungai
Tewalen di sebelah selatan, dan berada pada ketinggian 561,5 meter di atas permukaan laut. Sebelah selatan berbatasan dengan desa Motoling Kecamatan Motoling, sebelah utara berbatasan dengan desa Kumelembuai, sebelah timur berbatasan dengan desa Wanga dan sebelah barat berbatasan dengan desa Pakuure Kecamatan Tenga.

Potensi sumber daya manusianya cukup baik, dimana rata-rata penduduk dapat menempuh pendidikan hingga ke jenjang SMA dan bahkan sampai pendidikan tinggi. Juga terdapat tiga satuan pendidikan yakni: SD GMIM Malola, SD Inpres Malola Satu dan SMP Negeri. Mata pencarian penduduk sebagaian besar adalah petani, yang lain berprofesi pegawai negeri, tukang, dan wirausaha. Jika dilihat dari faktor ekonomi, sebagian besar penduduk tergolong ekonomi menengah meskipun tidak dapat dipungkiri sebagian penduduknya masih tergolong ekonomi lemah. Sedangkan dari letak geografis, desa ini jaraknya cukup jauh dari Ibukota Kabupaten apa lagi Ibukota Propinsi. Hal ini menyebabkan penduduk mengalami kesulitan untuk mengakses informasi, perkembangan ilmu pengetahuan dan teknologi.

\section{Permasalahan Mitra}

Dua sekolah dasar yang ada di desa Malola dan Malola Satu Kecamatan Kumelembuai Kabupaten Minahasa Selatan akan menjadi mitra dalam pelak-sanaan 
kegiatan pengabdian masyarakat oleh tim dari Lembaga Penelitian dan Pengabdian Masyarakat Universitas Negeri Manado. Hasil observasi dilapangan, dite-mukan beberapa permasalahan dalam pelaksanaan kegiatan belajar mengajar. Guru mengalami kesulitan menggambarkan dan mengkomunikasikan materi yang rumit dan kompleks. Guru juga belum memiliki kemampuan melakukan perekayasaan pembelajaran dengan menggunakan teknologi informasi dan komunikasi dalam pembelajaran. Disisi lain, ada potensi yang dapat menjadi sebuah keniscayaan untuk mengembangkan keterampilan mengajar guru, yakni sebagian besar guru sudah bisa mengoperasikan perangkat komputer. Potensi inilah yang memungkinkan untuk dilakukan pendidikan dan pelatihan pembuatan media pembelajaran audiovisual bagi guru dalam kegiatan belajar mengajar di sekolah. Oleh karena itu pihak pelaksana dan Kepala Sekolah bermufakat untuk melaksanakan program kegiatan pengabdian masyarakat ini.

\section{METODE PELAKSANAAN}

Metode yang diterapkan dalam pelatihan ini yaitu metode presentasi, metode demonstrasi, dan metode praktek. Metode presentasi diterapkan dalam pengenalan software, kemanfaataannya, dan penerapannya dalam pembuatan media pembelajaran audiovisual, Metode Demonstrasi mengenai pengoperasionalisasian program dan Metode Praktik dimana guru-guru mempraktek- kan secara langsung pembuatan media pembelajaran dengan pemanfaatan program Microsoft Power Point Hyperlink. Adapun langkah yang telah ditempuh dalam kegiatan P2M ini mencakup beberapa tahap berikut ini:

1. Tahap persiapan merupakan tahap awal sebelum pelaksanaan P2M. Dalam tahap ini ada beberapa hal yang dilakukan, yakni Koordinasi Internal, dilakukan oleh Tim untuk merencanakan pelaksanaan secara konseptual, operasional, serta job description masing-masing anggota, penentuan dan rekruitment peserta pelatihan. Dalam perekrutan peserta dipersyaratkan yang telah memiliki kemampuan yang memadai di bidang Komputer, pembuatan Instrumen P2M, seperti lembar presensi, angket, lembar kerja, persiapan konsumsi, publikasi, lokasi, dokumentasi, dan sebagainya.

2. Tahap ini merupakan tahap pelatihan yang diberikan kepada para guru sekolah dasar di desa Malola dan Malola Satu kecamatan Kumelembuai. Pelaksaannya mencakup beberapa hal berikut:

a. Penyajian materi, terkait dengan pengenalan dan penggunaan program Microsoft Power Point untuk pembuatan media pembelajaran audiovisual. Penyajian ini diploting dalam 10 tatap muka. Penyaji materi adalah tim pengabdi sendiri disesuaikan dengan bidang keahlian 
masing-masing. Materi yang tersajikan sebanyak 4 (empat) bahasan yang masing-masing disajikan oleh anggota Tim Pengabdi sesuai bidang yang bersangkutan. Kegiatan tanya jawab dilakukan bersamaan dengan penyajian materi. Para peserta dapat langsung berdiskusi dengan para pemateri secara langsung untuk memahamkan materi dan sharing pengalaman terkait dengan masalah yang tengah dibahas dalam materi bersangkutan;

b. Penugasan praktek, sesuai materi yang telah disajikan untuk menggali penyerapan dan pemahaman materi serta melihat kreativitasnya dalam berkarya. Dalam pelatihan ini para guru ditugaskan untuk membuat satu media pembelajaran terkait mata pelajaran yang diampu masing-masing guru. Tim pengabdi mendampingi, memandu dan mengarahkan serta memberikan solusi apabila timbul permasalahan selama penugasan praktek;

c. Evaluasi dan penyempurnaan, media yang telah dibuat oleh para guru dikumpulkan dan dinilai oleh tim pengabdi kemudian disempurnakan oleh tim untuk kemudian dikembalikan kepada peserta agar dapat digunakan untuk mengajar. Tindakan ini dilakukan mengingat karya media yang dihasilkan para guru masih perlu penyempurnaan, dan tim pengabdi ingin agar media pembelajaran betul-betul dapat segera dimanfaatkan untuk mengajar. Tahap selanjutnya tim pengabdi melakukan pendampingan dalam pengembangan media pembejaran berbasis multimedia; dan

d. Refleksi, di akhir kegiatan peserta dan Tim melakukan refleksi hasil pelatihan dan para peserta juga memberikan evaluasi akan pelatihan ini. Peserta mendapatkan koreksi dan evaluasi secara langsung terkait hasil karya mereka.

\section{HASIL DAN PEMBAHASAN}

Program pengabdian pada masya-rakat ini dilaksanakan sesuai dengan ren-cana dan jadwal yang telah ditetapkan. Kegiatan hari pertama diawali dengan pembukaan secara seremonial yang dihadiri oleh Hukum Tua Desa Malola sekaligus membuka kegiatan secara resmi, juga dihadiri oleh Badan Pekerja Majelis Jemaat GMIM Imanuel Malola sebab tempat pelaksanaan kegiatan adalah SD GMIM Malola dibawah binaan Komisi Pendidikan BPMJ GMIM Imanuel Malola. Pesertanya adalah guru-guru sekolah dasar yang ada di Desa Malola dan Malola Satu Kecamatan Kumelembuai Kabupaten Minahasa Selatan.

Materi yang disajikan adalah pengenalan dan penggunaan program Microsoft Power Point serta penjelasan mengenai hakikat 
media pembelajaran. Materi ini disajikan oleh Tim Pengabdi sesuai bidang keahlian yang dilaksanakan dalam 10 tatap muka. Materi yang disajikan dimulai dari hakikat media pembelajaran dan pengembangan soft skills dalam media pembelajaran oleh Ketua Tim. Materi selanjutnya adalah pengenalan, tips dan trik presentasi dengan menggunakan power point dan penggunaan $m s$ word dan excel ke dalam power point oleh Anggota Tim.

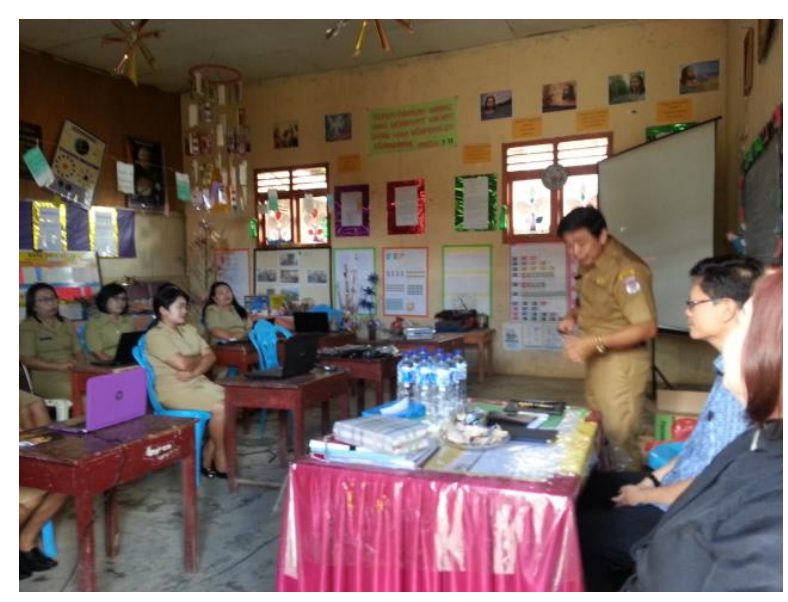

Gambar 1. Pembukaan kegiatan IbM oleh Pemerintah Desa Malola

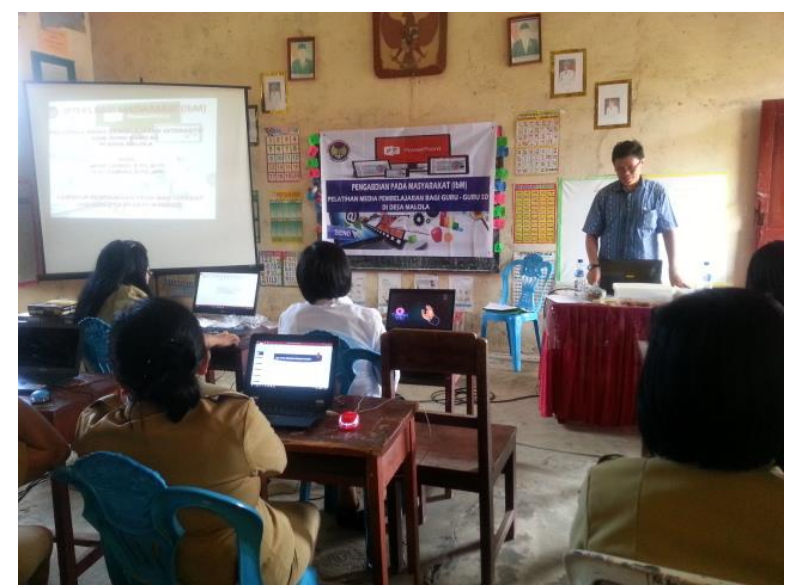

Gambar 2. Penyajian materi oleh Ketua Tim, Maxie Liando, M.Pd.

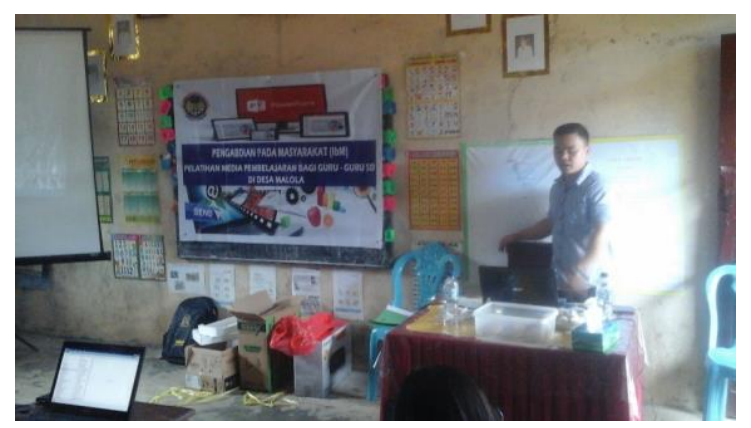

Gambar 3. Penyajian materi oleh Anggota Tim.

Proses pembimbingan dan praktek dilakukan bersamaan dengan penyajian materi. Para peserta dapat langsung bertanya dan berdiskusi dengan pemateri apabila menemui hambatan atau masalah terkait dengan materi yang dibahas. Pada akhir materi peserta diberi tugas membuat satu media pembelajaran terkait mata pelajaran yang diampu bagi guru mata pelajaran dan atau tematik bagi guru kelas sesuai dengan kurikulum pembelajaran. Tim pengabdi mendampingi, memandu dan mengarahkan serta memberi solusi terhadap permasalahan yang ditemui peserta ketika praktek berlangsung.

Salah satu komponen yang menentukan mutu pendidikan adalah guru. Guru harus selalu mengembangkan wawasan dengan mengupgrade perkembangan ilmu pengetahuan dan teknologi. Pemanfaatan teknologi informasi dalam proses belajar mengajar di kalangan guru cukup memprihatinkan, apalagi fasilitas penunjang teknologi pembelajaran belum memadai. Namun ada hal yang patut diberi apresiasi yakni adanya inisiatif para guru mengadakan fasilitas penunjang 
dimaksud meski harus dengan biaya sendiri. Dengan demikian penguasaan teknologi sebagai media pembelajaran dapat dikembangkan.

Upaya mengembangkan media pembelajaran interaktif agar pembelajaran yang diberikan oleh guru menjadi lebih atraktif perlu dikembangkan melalui pendidikan dan pelatihan. Hal inilah yang dilakukan oleh Tim P2M pada guru-guru sekolah dasar yang ada di Desa Malola Kecamatan Kumelembuai. Materi yang diberikan oleh Tim P2M dapat diterima dan dipahami peserta sebab kemampuan peserta tentang Microsoft office cukup memadai. Menguasai komputer dasar ini memang menjadi prasyarat yang diminta oleh Tim P2M pada guru-guru yang mengikuti pelatihan ini.

Metode yang digunakan secara simultan dimana para peserta dapat berkomunikasi langsung dengan pembawa materi sekaligus berfungsi sebagai instruktur, para guru dapat memahami urgensi pengembangan media pembelajaran. Peserta mampu menguasai fungsi program Ms. Power Point dan Hyperlink. Peserta juga bisa membuat media pembelajaran interaktif sesuai dengan mata pelajaran atau tema pembelajaran baik sebagai guru kelas maupun sebagai guru mata pelajaran. Cukup mengesankan melihat peserta bisa memanfaatkan program Ms. Power Point Hyperlink untuk membuat media pembelajaran. Beberapa tools dalam Ms. Power Point Hyperlink seperti membuat objek shape, menyisipkan objek movie dan sound, membuat efek animasi dan membuat tombol hyperlink bisa dilakukan peserta.

Hasil karya media pembelajaran yang dibuat para guru selama proses kegiatan berlangsung dievaluasi oleh tim dan diperoleh hasil rata-rata baik. Sekalipun demikian peserta belum dapat sepenuhnya membuat media pembelajaran audiovisual, melainkan masih sebatas pemanfaatan program Ms. Power Point Hyperlink dengan variasi yang cukup atraktif.

Adapun faktor penghambat adalah terbatsnya perangkat komputer atau laptop yang dimiliki oleh guru ataupun yang tersedia di sekolah. Untuk menutupi kekurangan ini Tim P2M membeli seperangkat komputer beserta printernya diserahkan kepada sekolah melalui Kepalah Sekolah disaksikan oleh guru-guru. Juga melakukan peminjaman laptop dan seperangkat $L C D$ Projecktor yang digunakan selang proses pendidikan dan pelatihan.

Hasil pelaksanaan kegiatan pendidikan dan pelatihan membuat media pembelajaran audiovisual dengan dasar power point hyperlink pada guru-guru yang ada di Desa Malola yang diselenggarakan oleh Lembaga Pengabdian Masyarakat Universitas Negeri Manado dalam bentuk program penerapan IPTEKS bagi masyarakat, dapat diuraikan sebagai berikut:

1. Berdasarkan hasil evaluasi baik menyangkut kehadiran, keterlibatan 
maupun peran aktif selama proses latihan hingga hasil pekerjaan yang dibuat peserta cukup memuaskan, meski hanya dalam waktu yang singkat. Para peserta berhasil mengerjakan beberapa latihan seperti menyajikan materi pelajaran ke dalam power point, membuat variasi model disertai dengan gambar animasi sederhana;

2. Semua peserta menunjukkan kesungguhan dan begitu antusias dalam mengikuti kegiatan pendidikan dan latihan dari awal sampai akhir, terutama saat membuat berbagai variasi yang terdapat pada menu power point baik secara individu maupun secara berkelompok;

3. Para peserta merasa beruntung mendapat kesempatan mengikuti diklat ini sebab diklat ini memberi kontribusi yang besar bagi peserta hingga memperoleh pengetahuan, pemahaman, dan keterampilan dalam membuat media pembelajaran power point dengan fasilitas hyperlink;

4. Para peserta menyatakan sangat beruntung mendapat kesempatan mengikuti pendidikan dan latihan membuat media pembelajaran sebab hal ini benar-benar mereka butuhkan dalam menunjang kinerja guru dalam proses belajar mengajar. Apalagi kegiatan pendidikan dan latihan ini diperoleh secara gratis;

5. Pemerintah Desa Malola dan juga Kepala Sekolah menyatakan rasa terima kasih kepada Lembaga Pengabdian
Masyarakat Universitas Negeri Manado atas pelaksanaan pendidikan dan latihan ini. Mereka berharap agar kegiatan serupa dapat dilakukan lagi di waktu yang akan datang sebagai tindak lanjut dari kegiatan ini; dan

6. Pemerintah Desa Malola dan juga Kepala Sekolah berterima kasih sebab mereka memperoleh dua manfaat langsung dari program P2M ini; yakni pengetahuan dan keterampilan membuat media pembelajaran audiovisual yang akan digunakan dalam proses belajar mengajar, dan seperangkat komputer beserta pencetak (printer) yang dapat dimanfaatkan secara langsung pasca pelaksanaan pendidikan dan latihan.

\section{KESIMPULAN DAN SARAN}

\section{Kesimpulan}

Berdasarkan hasil pelaksanaan pendidikan dan pelatihan pembuatan media pembelajaran pada guru-guru sekolah dasar di Desa Malola Kecamatan Kumelembuai, dapat disimpulkan beberapa hal sebagai berikut:

1. Pelatihan ini dapat memberi pengaruh dalam upaya peningkatan kualitas pembelajaran dengan pengetahuan dan keterampilan membuat media pembelajaran memanfaatkan program Ms. Power point Hyperlink sebagai teknolodi pembelajaran yang atraktif dan interaktif; 
2. Program IbM ini berlangsung dengan lancar sesuai dengan yang diharapkan, dan materi yang diberikan dapat diterima, dipahami dan dilakukan dengan baik; dan

3. Kegiatan P2M ini mendapat respon positif bahkan diapresiasi begitu baik oleh Pemerintah Desa (Hukumtua), Kepala Sekolah dan Guru-guru di desa Malola Kecamatan Kumelembuai.

\section{Saran}

Melihat keberhasilan dan manfaat yang dihasilkan dari Program P2M ini, saran yang dapat dilanjutkan melalui penerapan IbM adalah sebagai berikut:

1. Guru-guru peserta Diklat P2M melanjutkan pengembangan media pembelajaran interaktif seperti program Ms. Power point Hyperlink sebagai teknologi pembelajaran yang atraktif dan interaktif;

2. Pemerintah menyediakan fasilitas pendukung program berupa perangkat komputer atau laptop dan LCD Projector agar guru-guru dapat mengembangkan media pembelajaran sebagai pengejawatahan profesionalisme guru dalam menguasai teknologi informasi dalam kegiatan belajar mengajar.

\section{KEPUSTAKAAN}

Arsyad, Azhar. 2011. Media Pembelajaran. Jakarta: PT. Raja Grafindo Persada.

Aqib, Zainal, 2009, Menjadi Guru Profesional Berstandar Nasional, Yrama Widya, Bandung.

Dantes, Nyoman, 2006, Perspektif dan Kebijakan Pendidikan Menghadapi Tantangan Global,

Hamalik, Oemar, 2003, Pendidikan Guru Berdasarkan Pendekatan Kompetensi, Bumi Aksara, Jakarta.

Djamarah, Syaiful Bahri \& Aswan Zain. 2006. Strategi Belajar Mengajar. Jakarta: Rineka Cipta.

Panduan Pelaksanaan Penelitian dan Pengabdian Kepada Masyarakat Di Perguruan Tinggi. Edisi XI. Tahun 2017. Direktorat Riset dan Pengabdian Kementerian Riset, Teknologi dan Pendidikan Tinggi. 
Jurnal ABDIMAS, Vol. 11, No. 2, Agustus 2018

ISSN: 1979-0953 | e-ISSN: 2598-6066 